Article

\title{
Ferric Oxide-Containing Waterworks Sludge Reduces Emissions of Hydrogen Sulfide in Biogas Plants and the Needs for Virgin Chemicals
}

\author{
Tobias Persson, Kenneth M. Persson *(D) and Jenny Åström
}

Citation: Persson, T.; Persson, K.M.; Åström, J. Ferric Oxide-Containing Waterworks Sludge Reduces Emissions of Hydrogen Sulfide in Biogas Plants and the Needs for Virgin Chemicals. Sustainability 2021, 13, 7416. https://doi.org/10.3390/ su13137416

Academic Editor: Shashi Kant Bhatia

Received: 24 May 2021

Accepted: 28 June 2021

Published: 2 July 2021

Publisher's Note: MDPI stays neutral with regard to jurisdictional claims in published maps and institutional affiliations.

Copyright: (c) 2021 by the authors. Licensee MDPI, Basel, Switzerland. This article is an open access article distributed under the terms and conditions of the Creative Commons Attribution (CC BY) license (https:// creativecommons.org/licenses/by/ $4.0 /)$.
Sydvatten AB, Hyllie Stationstorg 21, SE-215 32 Malmö, Sweden; Tobias.Persson@Sydvatten.se (T.P.); Jenny.Astrom@Sydvatten.se (J.Å.)

* Correspondence: kenneth.persson@sydvatten.se

\begin{abstract}
Ferric oxide-containing waterworks sludge can be used to reduce the formation of hydrogen sulfide during anaerobic digestion. The ferric compound is reduced biochemically in the digester and forms insoluble pyrite in digester sludge. Virgin ferric chloride is often used to solve the hydrogen sulfide problem. Since 2013, Sydvatten AB has supplied a growing number of digestion plants in Sweden with ferric-containing dewatered waterworks sludge derived from the drinking water treatment plant Ringsjöverket to limit the formation of hydrogen sulfide. At the waterworks, ferric chloride is added to enhance the coagulation of organic matter from the source water. The sludge formed in this process is dewatered and landfilled, but also recycled in biogas production in order to decrease the hydrogen sulfide concentration. In this study, the use of sludge for hydrogen sulfide removal in digesters was technically and economically evaluated via case studies from 13 full-scale digesters in Sweden. Compared with the use of fresh ferric chloride, the operational costs are reduced by up to $50 \%$ by using sludge. The quality of the sludge is high and its content in metals is low or very low, especially when compared with the requirements of different certification standards for biosolid reuse applied in Sweden. The addition of waterworks sludge containing iron to a digester for the removal of dissolved hydrogen sulfide is a technically and economically good alternative when producing biogas. It is also one step closer to a circular economy, as replacing the use of virgin chemicals with the by-product waterworks sludge saves energy and materials and reduces the carbon footprint of the waterworks.
\end{abstract}

Keywords: biogas digestion; hydrogen sulfide; ferric oxide; waterworks sludge

\section{Introduction}

Biogas production is gaining increasing attention as a source for replacing fossil-based fuels with renewable fuels in society. Biogas is typically produced in anaerobic digestion plants (AD), where different substrates rich in organics are digested by methanogenic bacteria. Most substrates also contain sulfur, which in anaerobic environments can be microbiologically reduced to hydrogen sulfide, which negatively affects the metabolic activity of the methanogens and eventually poisons the digester. Additionally, hydrogen sulfide is a technical issue in plants and downstream when biogas is used, since hydrogen sulfide corrodes pipes, generators and other equipment. It is also a health hazard, being toxic to humans. Improving the quality and quantity of biogas usually requires pretreatment to maximize methane yields and/or post-treatment to remove hydrogen sulfide. This requires considerable energy consumption and higher costs; hence there are needs for better and more efficient measures to control hydrogen sulfide production [1].

One way to remove hydrogen sulfide as a gas is to add ferric salts to the substrate or to the digester. Ferric salts can be reduced to ferrous iron and form pyrite $\left(\mathrm{FeS}_{2}\right)$ as a precipitate. Often, ferric chloride solution is dosed into the reactor to achieve this removal effect on hydrogen sulfide. However, the addition of virgin ferric salts has an operational 
cost, and a water and carbon footprint. The profitability in, for instance, the Swedish biogas industry is relatively poor [2]. Swedish and European climate ambitions state that greenhouse gas emissions should be reduced to at least 55\% below 1990 levels by 2030, and be climate-neutral by 2050. Policies to help transition society towards a circular economy later on suggest a reduction in waste generation and the reuse and recycling of materials and energy, as expressed in the EU New Green Deal, the agenda for sustainable growth. The EU's transition to a circular economy will reduce pressure on natural resources and will create sustainable growth and jobs. It is also a prerequisite to achieve the EU's 2050 climate neutrality target and to halt biodiversity loss. Could other ferric materials with lower costs, smaller climate footprints and better material use replace the need for virgin ferric chloride? If so, the operational costs would decrease, the climate footprint would be reduced, and more biogas plants could achieve positive results, thus contributing to the EU New Green Deal.

The segment that has the greatest untapped potential for biogas production in Sweden, but also the biggest economic challenges, is the agricultural sector. Reducing the hydrogen sulfide concentration during digestion is presently associated with significant costs and the handling of corrosive chemicals. For farm-based biogas plants, this is extra stressful because these plants are small, and have small financial margins and limited resources for handling hazardous chemicals. In addition, manure (especially pig manure) is rich in sulfur and contains concentrations that can be converted to several thousand ppm hydrogen sulfide during the digestion process. How much hydrogen sulfide is formed during the digestion process depends on the sulfur content of the substrate in the form of sulfate or as sulfur bound in amino acids [3,4]. High costs for the removal of hydrogen sulfide can mean the difference between a positive and a negative financial result at the end of the year for a farm facility, and thus are also something that limits the expansion of biogas production in agriculture in Sweden. The removal of hydrogen sulfide also represents a significant cost in co-digestion plants. Requirements are higher for the separation of hydrogen sulfide in these plants, since the biogas produced is in principle exclusively upgraded to vehicle gas quality. In the case of biogas generated from sewage sludge in wastewater treatment plants, primarily those based on biological phosphorus separation have issues with high hydrogen sulfide concentrations during digestion. For these plants, a reduction in hydrogen sulfide is also associated with costs that make the biogas business less profitable, which is why alternative solutions can be of interest. Before upgrading the biogas, all sulfur must be removed, unless the upgrade is performed with a water scrubber, or in some cases an amine scrubber, as a few hundred ppm can be accepted. When the biogas is to be used for power/heat production, the requirements are usually around 50-200 ppm, but by lowering the concentration further, the service life can be increased and the need for maintenance on the engine/turbine used for power/heat production can be reduced.

The addition of an iron source, may it be iron chloride, iron oxides or waterworks sludge rich in iron salts, binds the hydrogen sulfide in the slurry in the digestion chamber, and reduces the possibility that the hydrogen sulfide can inhibit biogas production [3]. The addition of ferric salts can also increase the availability of trace metals that the microorganisms need, and thus increase the efficiency of the biogas process [5]. The addition of air and oxygen reduces the hydrogen sulfide concentration in the gas phase, but does not resolve the problem of hydrogen sulfide inhibiting the microorganisms in biogas production to the same extent. Furthermore, the use of oxygen/air in methane streams is associated with some risks, and it is important that biogas producers leave a sufficient margin to the lower explosion limit for biogas. It is not possible to use air if the biogas is to be upgraded to vehicle quality, as this requires that the oxygen in the air first be separated from the air nitrogen in an external process [6]. Ferric chloride and ferric oxide have similar properties when it comes to binding sulfide, with the difference that iron oxide is less reactive and less corrosive and thus easier to handle. Regardless of the method used, the reduction of hydrogen sulfide is associated with significant costs for the biogas producer, with the exception of those plants that use only air. A Swedish feasibility study for biogas 
production at farms [7] showed that the cost of hydrogen sulfide reduction was around EUR 0.01-0.02 per $\mathrm{Nm}^{3}$ biogas at farm biogas plants. The cost is higher for plants where the hydrogen sulfide level must be kept below $100 \mathrm{ppm}$ in the produced biogas.

Since 1997, Sydvatten AB has utilized ferric chloride as a coagulant in drinking water production at Ringsjöverket, the waterworks in Stehag, south Sweden. The coagulant forms a sludge that is gravimetrically removed from the sedimentation step in the waterworks. The waterworks sludge is dewatered in two steps and landfilled in an area previously used for peat extraction. Sydvatten AB has a sustainability plan laid out by the board of directors in 2018, stating, among other items, that resources should be utilized as efficiently as possible and that energy and material should be reused and recycled to the greatest possible extent [8]. The board of directors has stated that the company must be climateneutral by 2030, and the work on defining how climate neutrality can be reached and what measures must be taken in the organization to achieve climate neutrality has been reviewed in the Climate Accounts Report 2020 [9].

In 2016, tests were performed to investigate if the reuse of dewatered waterworks sludge could be applied in anaerobic digesters in the biogas industry in Sweden [10]. A growing number of biogas plants using varying sulfur-containing substrates means a growing need for efficient hydrogen sulfide management. To minimize the amounts of sludge deposited and to increase the recycling of materials is beneficial for society and reduces the costs and carbon footprint in the digester. The sludge contains mostly ferric oxide in various forms that originate from chemical precipitation with iron chloride in the waterworks. The purpose of this study is to technically and economically evaluate the use of the sludge for hydrogen sulfide reduction and to discuss to what extent the reuse of ferric waterworks sludge can contribute to the company reaching climate neutrality by 2030. A technical evaluation of the methods employed to add sludge to digesters and which specific dose of sludge should be added to digesters is also presented. We present some accounts from the field of the quantities of ferric compounds required to reduce the hydrogen sulfide concentration in different biogas plants.

The residual solids from the biogas production should be of such quality that they can be brought back to arable land as organic fertilizers when using ferric waterworks sludge as a hydrogen sulfide measure in the digester. Efficient material use requires these measures in a sustainable society. In Sweden, two different certification standards are used, depending on the origin of the substrate in biogas plants. If the substrate comes from a wastewater treatment plant, REVAQ is applied [11]. This is the national standard for the quality control of residuals from wastewater treatment plants and has been used since 2008 . If the substrate originates from other sources, such as manure or food waste, the SPCR 120 standard is used instead [12]. This certification standard has been developed by the solid waste industry in Sweden and has been used since 1999.

In substrates containing sulfur and rich in organic material, the anaerobic microbial metabolism generates sulfide and hydrogen sulfide, depending on the $\mathrm{pH}$. If iron is present, some iron is reduced microbiologically to ferrous iron. Pyrite $\left(\mathrm{FeS}_{2}\right)$ is a highly insoluble sulfide that can be formed in anaerobic conditions in the presence of sulfide ions. Waterworks sludge from drinking water treatment plants utilizing ferric salts for coagulation contains large amounts of ferric oxide. Mixing such sludge into the digester will cause the ferric ion $\left(\mathrm{Fe}^{3+}\right)$ to be reduced in the anaerobic environment to ferrous iron $\left(\mathrm{Fe}^{2+}\right)$, which binds sulfide ions to form pyrite. To dose ferric compounds into the digester is a method that can facilitate the removal of hydrogen sulfide from the biogas. It has been reported that around $2-4 \%$ of influent $S$ enters the digesters, which could be removed sufficiently by a dosage of $1.1 \mathrm{mg} / \mathrm{L}$ of Fe into the raw wastewater. A higher dry matter content was also observed in the dewatered cake as an additional secondary benefit when changing from alum dosage to iron dosage for phosphorous removal [13]. A drop in hydrogen sulfide emission from full-scale ADs at a large-scale municipal wastewater treatment plant could be achieved when dosing ferric chloride. The ferric salt was applied in the range of $24-105 \mathrm{mg} \mathrm{FeCl} 3 / \mathrm{L}$ into the feeding line and the sludge thickener unit. The hydrogen sulfide emission was 
reduced by $4 \mathrm{mg} / \mathrm{L}$ with the direct dosing into an $\mathrm{AD}$, but this emission was reduced by only $1.3 \mathrm{mg} / \mathrm{L}$ in non-dosed ADs. The formation of hydrogen sulfide could be correlated to the volatile primary sludge solid loading rates, based on data from a 17-month study period [14].

The waste iron powder produced by laser cutting machines in the steel and iron industry was mixed with dairy manure at a concentration between 2.0 and $20.0 \mathrm{~g} / \mathrm{L}$ in digestion batch experiments and between 1.0 and $4.0 \mathrm{~g} / \mathrm{L}$ in bench experiments. For batch experiments, the hydrogen sulfide concentration could be reduced by up to $93 \%$ at a dosage of waste iron powder of $2.0 \mathrm{~g} / \mathrm{L}$. If the waste iron powder concentration was higher than $8.0 \mathrm{~g} / \mathrm{L}$, the reduction was more than $99 \%$. Waste iron powder did not have a significant effect on methane yield in the batch and bench experiments, but the hydrolysis rate constant was almost doubled and the lag-phase period halved in test digesters compared to control digesters without iron dosage. In bench experiments, the $\mathrm{H}_{2} \mathrm{~S}$ concentration was reduced by $89 \%$ at $2.0 \mathrm{~g} / \mathrm{L}$, and by $50 \%$ at $1.0 \mathrm{~g} / \mathrm{L}$, without harming the digestion process [15].

$\mathrm{Fe}_{2} \mathrm{O}_{3}$ and $\mathrm{TiO}_{2}$ nanoparticles at four different concentrations in two different combinations, from 20 to $500 \mathrm{mg} / \mathrm{L}$, were used for the mitigation of hydrogen sulfide emission during the anaerobic digestion of cattle manure in a batch system. The $\mathrm{H}_{2} \mathrm{~S}$ production was 2.13-2.64 times lower than in the control. Additionally, biogas and $\mathrm{CH}_{4}$ production were 1.09-1.191 times higher than those of the control [16]. Titanium is relatively costly, and in another study, the researchers investigated whether directly adding waste iron powder and iron oxide nanoparticles into batch digesters could offer a more cost-efficient solution to hydrogen sulfide generation. By adding iron in the form of microscale iron powder at concentrations of $100 \mathrm{mg} / \mathrm{L}$ to $1000 \mathrm{mg} / \mathrm{L}$, the methane yield could be improved by up to $57 \%$. The equivalent dosages of iron nanoparticles improved the yield by up to $21 \%$. The highest iron powder dose $(1000 \mathrm{mg} / \mathrm{L})$ achieved the maximum improvement in the rate of hydrolysis, which was 1.25 times higher than in the control reactions. A high dosage of iron powder also decreased the rate of hydrogen sulfide production by up to $77 \%$ compared with the reference. The direct mixing of microscale iron powder was proposed as a practical and economical means of supporting the production of biogas from dairy manure [17].

The addition of iron-rich drinking water sludge directly into the urban domestic wastewater system was tested to reduce the content of dissolved sulfide in sewer systems, to aid phosphate removal in wastewater treatment, and to reduce hydrogen sulfide in the anaerobic digester. It was tested using two laboratory-scale urban wastewater systems, one as an experimental system and the other as a control, each comprising sewer reactors, a sequencing batch reactor (SBR) for wastewater treatment, sludge thickeners, and anaerobic digestion reactors. The experimental system received in-sewer drinking water sludge corresponding to $10 \mathrm{mg} \mathrm{Fe} / \mathrm{L}$, while the control had none. The addition of ferric sludge reduced the hydrogen sulfide concentration in the wastewater by $3.5 \mathrm{mg} \mathrm{S} / \mathrm{L}$ as compared with the control. The phosphate concentration decreased by $3.6 \mathrm{mg} \mathrm{P} / \mathrm{L}$ after biological wastewater treatment in the experimental SBR. In the experimental anaerobic digester, the sulfide concentration decreased by $16 \mathrm{mg}$ S/L compared with the reference. Drinking water sludge dosing also enhanced the settleability of the mixed liquid suspended sludge and the dewaterability of the anaerobically digested sludge. The cake solids concentration increased from $16 \%$ to $19 \%$. Additionally, the chemical oxygen demand (COD) and total suspended solids (TSS) concentrations in the wastewater were increased, but did not affect normal operation. The authors concluded that the addition of iron-rich drinking water sludge could be employed in the urban wastewater system, achieving multiple benefits [18].

Just over 2.1 TWh of biogas was produced in Sweden in 2019. Swedish biogas production increased by $3.3 \%$ in 2019, to a total of 2111 GWh (Table 1). Biogas production increased at all plant types except industrial plants and gasification plants in 2019. The largest increase was at digestion plants $(+68 \mathrm{GWh})$, which also accounted for most of the increase in the last decade. A total of $49 \%$ of the biogas was produced in co-digestion plants and $35 \%$ at sewage treatment plants. There are a total of 280 biogas production 
facilities in Sweden [19]. The biogas is mainly produced from various types of waste and residual products such as sewage sludge, food waste, manure and waste from the food industry and slaughterhouses. Increasing quantities of biogas are produced from manure. A total of 71 plants use fertilizer as a substrate, and the amount of manure that is digested has increased by $9 \%$ to 1.1 million tons. In total, around 2.8 million tons of digestate (wet weight) were produced at Swedish biogas plants in 2019, of which 2.4 million tons $(87 \%)$ were used as fertilizer in agriculture. From co-digestion plants and farm plants, all digestate (bio fertilizer) was used as fertilizer. From the sewage treatment plants, $41 \%$ of the digestate (digestate sludge) was used as fertilizer. Just under two-thirds of the biogas is upgraded. The long-term trend whereby an increasing amount of biogas is being upgraded continues, after a temporary decline in 2018. The upgraded biogas is used as vehicle gas or fed into the gas network. Of the biogas produced, $64 \%$ is upgraded $(1351 \mathrm{GWh})$ and $19 \%$ is used for heat production (Table 2). Direct electricity production continues to decline. The share of biogas that goes into flaring is a total of $11 \%$ of production, showing a definite increase up to 2018. Flaring has to be carried out during the start-up phases of digesters, and occasionally when operational problems occur. In 2019, a large new digester was commissioned, and the start-up issues took some time to solve [19].

Table 1. Volume of biogas production and number of plants in Sweden in 2019 per plant type and change since 2018 [19].

\begin{tabular}{ccccc}
\hline Plant Type & $\begin{array}{c}\text { Number } \\
\text { of Plants }\end{array}$ & $\begin{array}{c}\text { Production } \\
(\mathbf{G W h})\end{array}$ & $\begin{array}{c}\text { Share } \\
\mathbf{( \% )}\end{array}$ & $\begin{array}{c}\text { Change Since } \\
\mathbf{2 0 1 8} \mathbf{( \% )}\end{array}$ \\
\hline $\begin{array}{c}\text { Sludge from wastewater } \\
\text { treatment plants }\end{array}$ & 135 & 738 & 35 & +2 \\
Co-digesters & 36 & 1031 & 49 & +7 \\
Farm units & 50 & 58 & 3 & +4 \\
Industrial plants & 7 & 142 & 6 & -1 \\
Landfill gas plants & 52 & 142 & 7 & +1 \\
Gasification plants & 0 & 0 & 0 & -100 \\
Sum & 280 & 2111 & 100 & +3.3 \\
\hline
\end{tabular}

Table 2. Use of produced biogas in Sweden 2019 with change since 2018 [19].

\begin{tabular}{cccc}
\hline Area & Use (GWh) & Share (\%) & Change Since 2018 (\%) \\
\hline Upgrading & 1351 & 64 & 4 \\
Heat & 397 & 19 & -1 \\
Electricity & 38 & 2 & -10 \\
Industrial use & 52 & 2 & 0 \\
Other uses & 23 & 1 & -15 \\
Flaring & 235 & 11 & 11 \\
Losses and lack of data & 15 & 1 & 2 \\
Sum & 2111 & 100 & 3.3 \\
\hline
\end{tabular}

Of the upgraded biogas, 539 GWh was injected directly into the gas distribution network in south-west Sweden and in the regional network in Stockholm. In 2019, the total biogas use increased by $7 \%$, and the import was estimated at around $1.8 \mathrm{TWh}$, meaning the total biogas use in Sweden in 2019 was 4 TWh. The biogas market is growing in Sweden. Since 2015, it doubled, but the Swedish production only grew by a total of $9 \%$ during the same period [19]. Profitability in the Swedish biogas industry is relatively poor, and many biogas producers are struggling to achieve positive results. The segment that has the greatest untapped potential for biogas production in Sweden, but also the biggest economic challenges, is the agricultural sector. In order for there to be growth in this segment, it is necessary to be able to report profitability for the business. Reducing the hydrogen sulfide concentration during digestion is today associated with significant costs and the handling of corrosive chemicals. For farm-based biogas plants, this is extra stressful, because these 
plants are small, and have small financial margins and limited resources for handling hazardous chemicals. In addition, manure (especially pig manure) contains sulfur, which can be converted to several thousand ppm of hydrogen sulfide during the digestion process. How much hydrogen sulfide is formed during the digestion process depends on the sulfur content of the substrate in the form of sulfate or as sulfur bound in amino acids [3,4]. The high costs of hydrogen sulfide reduction can mean the difference between a positive and a negative financial result at the end of the year for a farm facility, and this is thus also something that limits the expansion of biogas production in agriculture in Sweden today.

The reduction of hydrogen sulfide is also a significant cost for co-digestion plants. Here, the requirements for the separation of hydrogen sulfide are higher than at farm-based biogas plants that produce power/heat, since the biogas produced at digestion plants is in principle exclusively upgraded to vehicle gas quality (see Table 2). In the case of wastewater treatment plants, it is primarily plants that perform biological phosphorus separation that experience high hydrogen sulfide concentrations during digestion. For these plants, a reduction in hydrogen sulfide is also associated with costs that make the biogas business less profitable, which is why alternative solutions can be of interest. Sulfur hydrogen is corrosive, and must be removed before the biogas is upgraded to vehicle fuel or used for power/heat production. Before upgrading biogas, all sulfur must be removed, unless the upgrade is performed with a water scrubber, or in some cases an amine scrubber, as a few hundred ppm can be accepted. When the biogas is to be used for power/heat production, the requirements are usually around 50-200 ppm, but by lowering the concentration further, the service life can be increased and the need for maintenance on the engine/turbine used for power/heat production can be reduced. The addition of iron chloride, iron oxides or waterworks sludge from the iron coagulation steps binds the hydrogen sulfide in the slurry in the digestion chamber, and reduces the probability of the hydrogen sulfide inhibiting biogas production [3].

\section{Materials and Methods}

Since 2013, iron-containing sludge derived from drinking water production at Sydvatten's waterworks in Stehag has been offered to biogas production plants in southern Sweden for hydrogen sulfide control. Sydvatten's interest is to minimize and eventually avoid the landfilling of waterworks sludge and find pathways to reusing the sludge in other applications. A survey of the properties of the waterworks sludge and how it has been used for counteracting hydrogen sulfide formation during biogas production has previously been reported [10]. The sludge contains mostly iron in various forms that originate from chemical precipitation with iron chloride in the waterworks.

Dewatered waterworks sludge was collected three times in 2016 and analyzed with reference to metal content at an accredited lab, AlControl AB. Sludge was collected from three different dewatering batches and mixed prior to analysis. Thirteen biogas producers from different sites in south Sweden who use waterworks sludge at full-scale for hydrogen sulfide removal were asked to share their experiences from these facilities, which have been collected and compiled below under different categories. Experiences concerning waterworks sludge transportation, transport cost, operational and maintenance costs for storage, the dosing and cleaning of the equipment used in the handling of waterworks sludge at the biogas plant, the practical dosage and use of waterworks sludge in the digester, the effects of storage conditions due to storage time and ambient temperature, and general operational observations of conditions when the waterworks sludge was dosed into the digester and mixed with substrate, were recorded in the interview series. All interviews were carried out through direct visits to the plants and through interviews with plant operators and managers.

\section{Results}

At Sydvatten's Ringsjöverket waterworks in Stehag, approximately 9000 tons of sludge with $15 \%$ total solids (TS) are produced annually (see Table 3). The sludge is formed in 
the chemical precipitate, which is the first part of the waterworks process. The raw water comes from Lake Bolmen in Småland, and the organic content of Bolmen's water is virtually inert, i.e., it will not contribute to the biogas production in the digestion chamber. Today, ferric chloride is used as a coagulation chemical to coagulate organic material in the water. The water $\mathrm{pH}$ is corrected with lye before the addition of the coagulant. The sludge settles in lamella sedimentation and is then thickened in a gravity thickener after the addition of iron chloride, lime water and polymer, so as to reach a dry content of about $2 \%$. The sludge is then pumped into a sludge handling plant where it is pressed in sieve belt presses after the addition of additional polymer and iron chloride to a dry content of about $15 \%$. The sludge is finally landfilled in a closed peat extraction area. Data on the overall generation of sludge and the fraction used in biogas plants are presented in Table 3.

Table 3. Waterworks sludge generation and fraction used for sulfide removal in biogas plants (Sydvatten, internal statistics).

\begin{tabular}{cccc}
\hline Year & \multicolumn{2}{c}{$\begin{array}{c}\text { Total Waterworks Sludge } \\
\text { Generation (tons) }\end{array}$} & $\begin{array}{c}\text { Fraction to Biogas Plants for } \\
\text { Hydrogen Sulfide Removal }\end{array}$ \\
\hline 2012 & Wet Weight & Total Solids & (\%) \\
2012 & 10,388 & 1558 & $0 \%$ \\
2013 & 10,388 & 1558 & $5 \%$ \\
2014 & 10,709 & 1606 & $10 \%$ \\
2015 & 9378 & 1407 & $16 \%$ \\
2016 & 9521 & 1428 & $27 \%$ \\
2017 & 7907 & 1186 & $40 \%$ \\
2018 & 6739 & 1011 & $34 \%$ \\
2019 & 8730 & 1310 & $56 \%$ \\
2020 & 7682 & 1152 & $56 \%$ \\
\hline
\end{tabular}

There are operating situations at the waterworks when no iron-containing sludge is produced. This occurs especially if there is a landslide in the tunnel that runs between Lake Bolmen in Småland and Ringsjöverket. This has historically occurred on three occasions over the past 30 years, and then the tunnel has had to be drained and renovated. On these occasions, water from Ringsjön is used at the waterworks and then an aluminum-based precipitation chemical is used instead of iron chloride. The sludge formed then cannot be used in the biogas industry. These malfunctions usually take between one and two years to rectify. It is therefore important for biogas producers who choose to use the waterworks sludge to be able to switch quickly to an alternative solution, such as ferric chloride, during such a period.

The waterworks sludge from Ringsjöverket has a black-brown appearance (see Figure 1), and if it has been in contact with air for a while, small black iron crystals form on the surface. The sludge is water-soluble and has a slight iron odor. Its density is around $1.1 \mathrm{~kg} / \mathrm{dm}^{3}$, and the sludge is slightly acidic, with a $\mathrm{pH}$ value around 4.2 . The sludge consists mostly of iron compounds (about $30 \%$ iron and $>40 \%$ iron oxides) and various organic compounds (about 25\% TOC). In the waterworks, before the sludge is separated, only iron chloride and lye are added. Then, a small amount of the drinking water-grade polymer Magnafloc LT22S-DWI is added together with additional iron chloride in both the thickener and the screen belt press to facilitate dewatering [10]. 


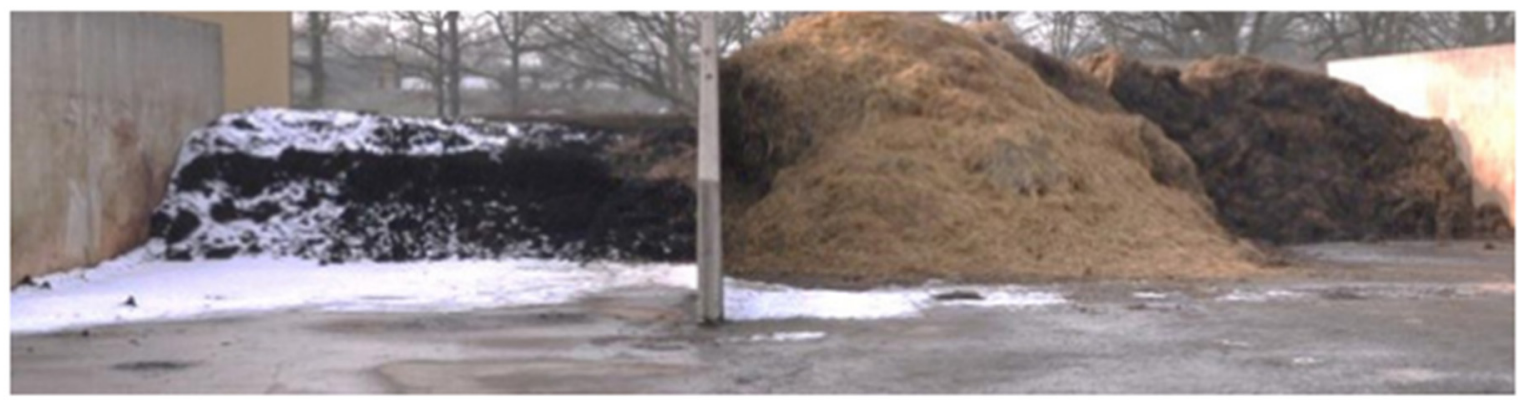

Figure 1. Waterworks sludge (left) and manure storage (right). Photo: Annika Nyberg.

A detailed metal analysis has been carried out on the dewatered sludge from Ringsjöverket on three different occasions. Results for the most relevant metals are reported in Table 4. Table 4 compares the analysis results with the limit values that exist within Avfall Sverige's certification rules for biofertilizers, SPCR 120 [12] and the Swedish Environmental Protection Agency's general guideline values for contaminated land for sensitive land use, published in 2009 [20]. It is clear that the metal content of the waterworks sludge is below these levels by a very good margin for virtually all metals. Only the limit value for arsenic in the sludge is in the same order of magnitude as the Swedish Environmental Protection Agency's guideline value for contaminated soil in sensitive land use. Revaq is a certification system that has the aim of reducing the flow of hazardous substances to treatment plants and creating a sustainable return of plant nutrients by spreading sludge from wastewater treatment plants on arable land [11]. The heavy metals that hold the greatest interest in Revaq and that require the most frequent analysis intervals within Revaq are lead, cadmium, copper, chromium, nickel, zinc, mercury, silver and tin, and analysis results from all of these are included in Table 4. Even in this case, the concentrations are low compared to the guideline values that exist. Table 4 also shows that the iron content is relatively constant during the year, with only small variations. This is important for biogas producers to be able to use a similar dosage for different sludge deliveries.

Table 4. Composition of waterworks sludge from Ringsjöverket compared with guideline values from Swedish EPA [20] and the Swedish Waste Association standard SPCR 120 [12] for permissible metal content for biosolids reuse.

\begin{tabular}{|c|c|c|c|c|c|c|}
\hline Metal & $\begin{array}{l}\text { Guideline Value from } \\
\text { Swedish EPA for } \\
\text { Contaminated Land }\end{array}$ & SPCR 120 & 12 October 2015 & 11 April 2016 & 27 June 2016 & Unit \\
\hline Antimony & 12 & & $<2.1$ & $<2.1$ & $<2.1$ & $\mathrm{mg} / \mathrm{kg}$ TS \\
\hline Arsenic & 10 & & 7.2 & 5.1 & 8.6 & $\mathrm{mg} / \mathrm{kg}$ TS \\
\hline Barium & 200 & & 40 & $<23$ & 45 & $\mathrm{mg} / \mathrm{kg}$ TS \\
\hline Cadmium & 1.5 & 1 & $<0.11$ & $<0.11$ & 0.13 & $\mathrm{mg} / \mathrm{kg}$ TS \\
\hline Chromium & 80 & 100 & 12 & 18 & 15 & $\mathrm{mg} / \mathrm{kg}$ TS \\
\hline Cobalt & 15 & & 4.3 & 5 & 4.7 & $\mathrm{mg} / \mathrm{kg}$ TS \\
\hline Copper & 80 & 600 & 11 & 17 & 15 & $\mathrm{mg} / \mathrm{kg}$ TS \\
\hline Iron & & & 30 & 29 & 28 & $\%$ of TS \\
\hline Lead & 50 & 100 & 6.5 & 5.3 & 11 & $\mathrm{mg} / \mathrm{kg} \mathrm{TS}$ \\
\hline Mercury & 0.25 & 1 & $<0.051$ & $<0.051$ & 0.052 & $\mathrm{mg} / \mathrm{kg}$ TS \\
\hline Molybdenum & 40 & & 4.1 & 4.5 & 4.1 & $\mathrm{mg} / \mathrm{kg}$ TS \\
\hline Nickel & 40 & 50 & 5.5 & 5.3 & 6.7 & $\mathrm{mg} / \mathrm{kg}$ TS \\
\hline Silver & & & $<0.51$ & $<0.51$ & $<0.52$ & $\mathrm{mg} / \mathrm{kg}$ TS \\
\hline Tin & & & $<0.51$ & 0.7 & 0.82 & $\mathrm{mg} / \mathrm{kg}$ TS \\
\hline Vanadium & 100 & & 47 & 47 & 64 & $\mathrm{mg} / \mathrm{kg}$ TS \\
\hline Zinc & 250 & 800 & 49 & 50 & 65 & $\mathrm{mg} / \mathrm{kg}$ TS \\
\hline
\end{tabular}

In 2016, waterworks sludge was accepted as an approved additive to the digestion process within the certification system SPCR 120. Therefore, it is now possible for the biogas plants that have this certification to use the waterworks sludge to reduce the hydrogen 
sulfide concentration in the biogas. When it comes to certification according to Revaq, the use of the waterworks sludge should only affect the cadmium $(\mathrm{Cd}) /$ phosphorus $(\mathrm{P})$ ratio marginally, because the cadmium content is very low. However, the phosphorus content is also low, which means that even a low cadmium concentration can have a negative effect on the $\mathrm{Cd} / \mathrm{P}$ ratio. The size of the sludge feed is also affected because this is regulated not only by the metal concentration, but also by the amount of a certain metal that may be laid per unit area. This applies in particular to the metals lead, cadmium, chromium, nickel, zinc and mercury. However, the content of these metals is very low, and should only have a minor impact. The rules for the Revaq certification system state, however, that "The certificate holder shall not receive such material that is deemed to adversely affect the quality of sludge, through low nutrient content or high content of contaminants. The 60 trace elements must always be analyzed before receiving a new type of material". This can be a problem for the use of waterworks sludge in Revaq-certified treatment plants, but it is not really different from using ferric chloride to reduce the hydrogen sulfide concentration, as it also contains some other heavy metals.

During the project, 13 biogas producers that use waterworks sludge at the full scale were contacted. The experiences at these facilities have been collected and compiled below under different categories. Some of the results have already been published in a report in Swedish [10].

\subsection{Transport Cost}

The transport cost varies between different biogas producers depending on the distance and how the transport is performed. Some use trucks with trailers and others without. Some drive a few kilometers while others drive up to $600 \mathrm{~km}$. In addition to the actual transport of the sludge, the transporter must also spend time cleaning the platform afterwards. The cost reported by the biogas producers in different parts of the country varies between EUR 15 and 40/ton of waterworks sludge, with 15\% TS.

\subsection{Other Costs}

In addition to transport, biogas producers face costs for the storage, dosing and cleaning of the equipment used. For most users of waterworks sludge for hydrogen sulfide control, these costs are considered to be marginal and estimated at somewhere between EUR 2 and 10/ton wet waterworks sludge.

Most of the biogas producers who currently use waterworks sludge have previously used iron chloride that they bought from a chemical supplier. The cost of virgin iron chloride is up tp twice as high as the total handling costs of the waterworks sludge. The location of the plant matters. A large transport cost reduces the net savings of operational costs. According to Broberg [7], the cost of hydrogen sulfide reduction with iron chloride and iron oxide is around EUR $0.01-0.02$ per $\mathrm{Nm}^{3}$ in farm biogas plants. The cost of using waterworks sludge ends up in the same order of magnitude if the cost of handling and transport is estimated at approximately EUR 40 per ton. However, several biogas producers have reported substantially lower transport and handling costs, and in addition, they reduced the hydrogen sulfide concentration to lower levels when using the sludge compared to when they used ferric chloride. This supports the conclusion that cost savings of up to $50 \%$ are possible, but that this depends on the transport cost. The reason for the further reduction in the hydrogen sulfide concentration with sludge is that they think they can afford to add a surplus of iron to the digester, since the marginal material cost is lower, and thus they can then control the dosage towards a lower hydrogen sulfide concentration in the generated biogas. A lower residual hydrogen sulfide concentration in the biogas increases the life of the power/heating unit and reduces its maintenance needs and costs. If the substrate used has lower sulfate content, the amount of sludge needed per volume of biogas produced is lower. Other benefits that the operators of the biogas production plants have observed is the easier handling of waterworks sludge when dosing compared to the corrosive ferric chloride solution and the corrosive damage to the equipment that this can 
lead to. Some of the farm biogas producers have previously used only aeration or aeration in combination with iron additive. Then, the economic gain achieved with the transition to waterworks sludge is smaller because the addition of air is associated with very marginal costs.

\subsection{Use of Waterworks Sludge in the Digester}

The number of plants that utilize waterworks sludge from Ringsjöverket has increased since the test started in 2013. In 2020, a total of 24 different plants collected iron-containing waterworks sludge for hydrogen sulfide removal in the digesters. Based on information from seven biogas plants where only manure is used as the substrate, one ton of wet waterworks sludge (with a TS of 15\%) is sufficient to produce an average of $2700 \mathrm{Nm}^{3}$ of biogas if the hydrogen sulfide concentration in the biogas is to be reduced below $100 \mathrm{ppm}$. This corresponds to about $0.2-0.5 \%$ of the amount of substrate added, expressed as dry matter. The stoichiometric relation between sulfur and iron could be observed at another biogas plant where the residual hydrogen sulfide content was allowed to be higher. This plant was designed to produce biogas with a residual hydrogen sulfide concentration below $300 \mathrm{ppm}$. An addition of one ton of waterworks sludge to the digester was enough to produce $8000 \mathrm{Nm}^{3}$ of biogas with $<300 \mathrm{ppm}_{2} \mathrm{~S}$.

In co-digestion plants where a mixture of manure, starch, food waste and slaughterhouse waste is applied, one ton of wet waterworks sludge was sufficient to reduce the hydrogen sulfide concentration in a significantly larger volume of biogas, since the mix of substrate contains less sulfur than pure manure. Five co-digestion plants surveyed in this study dosed less than half the amount of waterworks sludge into the substrate compared with the manure-based biogas plants, and could still generate biogas with less than 100 ppm hydrogen sulfide. If the proportion of manure dominates in the substrate, the required addition of waterworks sludge remains high, since that kind of substrate is similar to pure manure. The iron in waterworks sludge is less available compared to the addition of pure ferric chloride solutions to control the hydrogen sulfide concentration. When comparing the addition of iron from waterworks sludge with ferric chloride solution, the total amount of iron added to the substrate had to be increased 2.5 to 3 times if added as waterworks sludge in order to achieve a similar effect on hydrogen sulfide removal, compared with the dosing of ferric chloride solution.

\subsection{Impact of Temperature and Storage of Waterworks Sludge}

Out of 13 surveyed plants, 1 had experienced a slight loss of efficiency resulting from waterworks sludge dosing in the summer. When stored for a long time in the summer, the waterworks sludge lost some of its function, since iron crystals were formed on the sludge surface when it dried in the sun. The iron in the crystals was less available for the microorganisms in the digester. Only one of the producers surveyed identified this as problematic. The storage of sludge in a shaded environment and the modest addition of moisture to the sludge could mediate this issue.

\subsection{Observed Operational Conditions When Mixing Waterworks Sludge with Substrate and Feeding the Mix into Digesters}

The mixing and feeding of waterworks sludge into the digester was generally a carefree process. Very few problems have been experienced in connection with the handling of the waterworks sludge in biogas plants. The exception was for biogas plants utilizing solid substrates. In these plants, the substrate is mixed with waterworks sludge and fed into the digestion chamber with a screw. The screw is designed for handling dry materials. If the substrate becomes too wet after mixing with the sludge, it slides backwards and stops following the screw. With less feed into the digester, the production decreases. The solution to the problem is to mix the sludge with drier materials and preferably also with longer straw in the substrate. In one of these plants, it was observed that some of the waterworks sludge remained at the bottom of the digestion chamber when it was opened. No action 
has been taken, but this suggests that the dissolution of the sludge is slow when it is fed together with solid material.

In most of the plants that use liquid substrates, the waterworks sludge is scooped into a mixing well. In these wells the $\mathrm{pH}$ is often quite low and the stirring is vigorous. A low $\mathrm{pH}$ facilitates the dissolution of the sludge as the solubility of the iron increases with decreasing $\mathrm{pH}$. Those who use this type of mixture have not experienced any problems with dissolving the sludge, nor have they seen any residues of undissolved sludge in the mixing well when it has been drained. For wastewater treatment plants, operators have expressed concerns that the addition of waterworks sludge could affect the drainage properties of the digestate. The opposite effect is indicated by literature data, finding that the drainage of biosolids after the addition of waterworks sludge is improved $[13,18]$.

\subsection{Transportation of Waterworks Sludge into the Digestion Plant}

The waterworks sludge is slightly adhesive and may get stuck on the flatbed when transported. For this reason, various measures have been taken to make handling and cleaning easier. Many people have added straw or sawdust to the flatbed before loading the sludge to make cleaning easier. Another possibility is to spray the flatbed with rapeseed oil or similar prior to loading. There is also a risk in cold climates that the sludge gets stuck on the platform due to freezing. In wintertime, it may be necessary to transport the sludge in closed containers.

\section{Discussion}

Assuming that the waterworks sludge is virtually inert and does not degrade in the digestion chamber, the entire dry content of the added waterworks sludge will pass through the digestion chamber and be present in the residual biosolids. Based on the information collected from the examined biogas plants included in the study, the waterworks sludge contributes to an increased amount of digestate; that is, about $1-3 \%$ based on dry matter, i.e., about $1-3 \%$ of TS. The digestate in most plants has a TS content of around $5 \%$, while the waterworks sludge has a TS content of around $15 \%$. The volume increase in the digestate to be handled due to the addition of waterworks sludge is $1 \%$ at the most; the TS content in the digestion increases by about $0.1-0.3 \%$, while the total amount of metals in the digestate increases by approximately 1-3\% (see calculation in Table 5). Table 5 also refers to the quality requirements according to the biofertilizer certification system, SPCR 120 [12]. This standard states that the proportion of each of the metals (lead, cadmium, copper, chromium, mercury and zinc) may not exceed $15 \%$ of the total amount of the metal in the certified biofertilizer. In addition, the nickel content in the biofertilizer from the waterworks sludge must not exceed $6 \mathrm{mg} / \mathrm{kg}$ biofertilizer (wet weight). In 2019, around 2.8 million tons of digestate (wet weight) was produced in Sweden, of which $87 \%$ was used as fertilizer in agriculture [19]. From farm plants and co-digestion plants, 2.13 million tons, virtually all digestate (biofertilizer), was used as fertilizer. From the wastewater treatment plants, 0.25 million tons ( $41 \%$ of all the sludge) was used as fertilizer certified in the Revaq system. The remaining amount was used mainly as construction material or for the final coverage of landfills [19]. No biosolids are generated at landfill gas plants.

The biogas production from the other plants that also generate biosolids corresponds to a total of $1969 \mathrm{GWh}$ [17]. These plants simultaneously produced 2.8 million tons of biosolids, or around $700 \mathrm{kWh} /$ ton of biofertilizer. Assuming that $1 \mathrm{Nm}^{3} \mathrm{CH}_{4}$ corresponds to $9.81 \mathrm{kWh}$ [21] and that the biogas contains $65 \%$ methane [22], this corresponds to a production of $110 \mathrm{Nm}^{3}$ of biogas per ton of biofertilizer. According to the values for the 13 plants using waterworks sludge from Ringsjöverket surveyed above, around 1 ton of waterworks sludge is added per $8750 \mathrm{Nm}^{3}$ of biogas that has been produced. This corresponds to adding 1 ton of waterworks sludge per 108 tons of biofertilizer produced in the plant, excluding the added waterworks sludge, or $9.2 \mathrm{~kg}$ of waterworks sludge per ton of biofertilizer produced. Table 5 shows how adding waterworks sludge affects the concentration of metals in the biofertilizer. The starting point for the calculation is the 
average value of the metal contents in the biofertilizer for the 18 plants that were certified within SPCR 120 in 2014 [23]. Nickel is not included as there is no risk that the content of nickel can reach up to $6 \mathrm{mg} / \mathrm{kg}$ wet weight given the concentration of nickel present in the waterworks sludge. Among other heavy metals, lead and chromium make up the largest parts of the total metal concentration, at 7 and $6 \%$, respectively. However, this is below the limit of $15 \%$ specified according to SPCR 120 . Therefore, this is also not considered to be a problem for the use of waterworks sludge. With the addition of the waterworks sludge, which is assumed to be inert, the $\mathrm{S}$ content of the biofertilizer increases. Assuming the same waterworks sludge dose as above, the TS in the biofertilizer increases from 3.9 to $4.0 \%$. An effect of this is that the concentration of metals, stated as $\mathrm{mg} / \mathrm{kg} \mathrm{TS}$, decreases for, e.g., copper and zinc, while the concentration increases slightly for lead and chromium (see Table 5).

Table 5. Average concentration of heavy metals in biofertilizer for the facilities that were certified in 2014 [23] before and after an estimated addition of waterworks sludge. The TS in the biofertilizer is $3.9 \%$ before the addition of waterworks sludge. The concentration in the sludge is the average of analyzed data according to Table 3.

\begin{tabular}{cccccccc}
\hline & Unit & $\mathbf{P b}$ & $\mathbf{C d}$ & $\mathbf{C u}$ & $\mathbf{C r}$ & $\mathbf{H g}$ & $\mathbf{Z n}$ \\
\hline Concentration in biofertilizer & $\mathrm{mg} / \mathrm{kg}$ TS & 3.6 & 0.4 & 89 & 8.3 & 0.06 & 292 \\
Concentration in biofertilizer & $\mathrm{mg} / \mathrm{kg}$ DS & 0.14 & 0.016 & 3.47 & 0.32 & 0.002 & 11.4 \\
Concentration in waterworks sludge & $\mathrm{mg} / \mathrm{kg}$ & 1.15 & 0.019 & 2.15 & 2.25 & 0.01 & 8.27 \\
Content in 9.2 g waterworks sludge & $\mathrm{mg}$ & 0.011 & 0.0002 & 0.020 & 0.041 & 0.00007 & 0.150 \\
Total amount in 1 kg bio fertilizer + 9.2 g & $\mathrm{mg}$ & 0.15 & 0.016 & 3.49 & 0.34 & 0.002 & 11.5 \\
$\begin{array}{c}\text { waterworks sludge } \\
\text { Fraction of metals from waterworks sludge }\end{array}$ & $\%$ & 7.0 & 1.1 & 0.6 & 6.0 & 3.0 & 0.7 \\
Total concentration in biofertilizer produced & $\mathrm{mg} / \mathrm{kg}$ TS & 3.7 & 0.4 & 86 & 8.4 & 0.06 \\
with waterworks sludge & & & & & & &
\end{tabular}

Since about half of the waterworks sludge consists of various organic compounds from lake-source water, the waterworks sludge contributes to the increased organic content in soil where the digestate is spread as fertilizer. In many Swedish soils, the organic content is low, which is why this is a welcome contribution to improving the soil's properties. The organic content in soils improves the physical, chemical and biological properties of the soil, such as its water holding capacity, nutrient content, buffer capacity, and the activity of soil organisms.

To reuse material is beneficial for climate and society, and reduces the carbon footprint. According to the evaluation in Sydvatten's Climate Account Report 2020, the production of virgin iron chloride generates about $0.395 \mathrm{~kg} \mathrm{CO}_{2}$ emission per $\mathrm{kg} \mathrm{FeCl}_{3}$. Since Sydvatten used 3132 tons of $\mathrm{FeCl}_{3}$ in 2020 for drinking water treatment, the reuse of $56 \%$ sludge by replacing virgin ferric chloride with waterworks sludge would eliminate 740 tons of carbon dioxide, which is about $17 \%$ of all the carbon dioxide that was emitted by the company in 2020 [9], and is well in accordance with EU's Circular Economy Plan [24].

\section{Conclusions}

Waterworks sludge that contains iron works very effectively as an additive to reduce the hydrogen sulfide concentration in biogas production. This has been demonstrated in the 13 full-scale biogas plants surveyed in this project. According to the costs reported for the transport and handling of the sludge, there is potential to save up to $50 \%$ compared to a scenario in which these plants use virgin ferric chloride instead. In the manure-based biogas plants, one ton of waterworks sludge with $15 \%$ TS is sufficient to reduce the hydrogen sulfide concentration to below $100 \mathrm{ppm}$ in $2-3000 \mathrm{Nm}^{3}$ biogas. In the digestion plants that participated in the study, the same amount of sludge was enough for more than twice as much gas-about $8000 \mathrm{Nm}^{3}$. In both cases, the exact figure depends on the substrate composition and the level at which the hydrogen sulfide concentration is reduced. The content of heavy metals in the waterworks sludge is well below the concentrations used in 
Avfall Sverige's certification system, SPCR 120, for the reuse of biosolids from solid waste plants. The reuse of $56 \%$ of the sludge by replacing virgin ferric chloride with waterworks sludge saves 740 tons of carbon dioxide, corresponding to about $17 \%$ of all carbon dioxide emitted by Sydvatten in 2020 .

Author Contributions: Conceptualization, T.P. and K.M.P.; methodology, T.P., investigation, T.P., K.M.P. and J.Å.; writing, T.P., K.M.P. and J.Å. All authors have read and agreed to the published version of the manuscript.

Funding: This research received no external funding.

Acknowledgments: Lars Månsson and Irene Bohn are acknowledged for sampling and other technical support in the project.

Conflicts of Interest: The authors declare no conflict of interest.

\section{References}

1. Wellinger, A.; Murphy, J.D.; Baxter, D. The Biogas Handbook. Science, Production and Applications Woodhead Publishing; Woodhead Publishing Series in Energy no. 52; Elsevier: Amsterdam, The Netherlands, 2013; 512p.

2. Ahlberg-Eliasson, K.; Nadeau, E.; Levén, L.; Schnürer, A. Production efficiency of Swedish farm-scale biogas plants. Biomass Bioenergy 2017, 97, 27-37. [CrossRef]

3. Schnürer, A.; Jarvis, Å. Mikrobiologisk Handbok för Biogasanläggningar. SGC-Rapport 207. 2009. Available online: http: //www.sgc.se/ckfinder/userfiles/files/SGC207.pdf (accessed on 11 May 2021).

4. Möestedt, J.; Påledal Nillson, S.; Schnürer, A. The effect of substrate and operational parameters on the abundance of supphate reducing bacteria in industrial anaerobic biogas digester. Bioresour. Technol. 2013, 132, 327-332. [CrossRef]

5. Yekta, S.S. Chemical Speciation of Sulfur and Metals in Biogas Reactors. Implication for Cobolt and Nickel Bio-Uptake Processes. Ph.D. Thesis, The Department of Thematical Studies-Environmental Change Linköping University, Linköping, Sweden, 2014.

6. Bauer, F.; Hulteberg, C.; Persson, T.; Tamm, D. Biogas upgrading-Review of commercial technologies. SGC Rapp. 2013, $2013,270$. Available online: http:/ / www.sgc.se/ckfinder/userfiles/files/SGC270.pdf (accessed on 11 May 2021).

7. Broberg, A. Metoder för Svavelvätereducering, Hushållningsskapets Förbund 2013. 2013. Available online: http://www. bioenergiportalen.se/attachments/42/691.pdf (accessed on 11 May 2021).

8. Sydvatten 2021A: Sustainability Report. 2020. Available online: https://sydvatten.se/app/uploads/2021/04/Hallbarhetsredovisning 2020_Sydvatten.pdf (accessed on 11 May 2021). (In Swedish)

9. Sydvatten 2021B: Climate Account Report. 2020. Available online: https://sydvatten.se/app/uploads/2021/04/Klimatbokslut_ 2020_Sydvatten.pdf (accessed on 11 May 2021). (In Swedish)

10. Tobias, P.; Lars, M.; Irene, B. Vattenverksslam Reducerar Biogasens Svavelväte. Rapport 2017, 344. Energiforsk, Stockholm. Available online: https:/ / energiforskmedia.blob.core.windows.net/media/22106/vattenverksslam-reducerar-biogasens-svavelvateenergiforskrapport-2017-344.pdf (accessed on 14 May 2021).

11. Svenskt Vatten 2020: REVAQ-Rules for Certification. Available online: https://www.svensktvatten.se/globalassets/avlopp-ochmiljo/uppstromsarbete-och-kretslopp/revaq-certifiering/revaq-regler-2021---utgava-7.0-gul.pdf (accessed on 11 May 2021).

12. Avfall Sverige 2021: SPCR 120. Certification Rules. Available online: https://www.avfallsverige.se/kunskapsbanken/certifieradatervinning/certifieringsregler/ (accessed on 11 May 2021). (In Swedish)

13. Parker, W.; Celmer, R.D.; Bicudo, J.; Law, P. Assessment of the use of mainstream iron addition for phosphorous control on H2S content of biogas from anaerobic digestion of sludges. Water Environ. Res. 2020, 92, 338-346. [CrossRef] [PubMed]

14. Erdirencelebi, D.; Kucukhemek, M. Control of hydrogen sulphide in full-scale anaerobic digesters using iron (III) chloride: Performance, origin and effects. Water SA 2018, 44, 176-183. Available online: https:/ / search.ebscohost.com/login.aspx?direct= true \&db=a9h\&AN=129677686\&site=eds-live\&scope $=$ site (accessed on 11 May 2021). [CrossRef]

15. Andriamanohiarisoamanana, F.J; Shirai, T.; Yamashiro, T.; Yasui, S.; Iwasaki, M.; Ihara, I.; Nishida, T.; Tangtaweewipat, S.; Umetsu, K. Valorizing waste iron powder in biogas production: Hydrogen sulfide control and process performances. J. Environ. Manag. 2018, 208, 134-141. Available online: https:// search.ebscohost.com/login.aspx?direct=true\&db=edselp\&AN=S030147971 731174X\&site=eds-live\&scope $=$ site (accessed on 11 May 2021). [CrossRef] [PubMed]

16. Farghali, M.; Andriamanohiarisoamanana, F.J; Ahmed, M.M.; Kotb, S.; Yamashiro, T.; Iwasaki, M.; Umetsu, K. Impacts of iron oxide and titanium dioxide nanoparticles on biogas production: Hydrogen sulfide mitigation, process stability, and prospective challenges. J. Environ. Manag. 2019, 240, 160-167. Available online: https://search.ebscohost.com/login.aspx?direct=true\&db= edselp\&AN=S0301479719303925\&site=eds-live\&scope $=$ site (accessed on 11 May 2021). [CrossRef]

17. Farghali, M.; Andriamanohiarisoamanana, F.J.; Ahmed, M.M.; Kotb, S.; Yamamoto, Y.; Iwasaki, M.; Yamashiro, T.; Umetsu, K. Prospects for biogas production and $\mathrm{H} 2 \mathrm{~S}$ control from the anaerobic digestion of cattle manure: The influence of microscale waste iron powder and iron oxide nanoparticles. Waste Manag. 2020, 101, 141-149. Available online: https:/ /search.ebscohost.com/ login.aspx?direct=true\&db=cmedm\&AN=31610475\&site=eds-live\&scope=site (accessed on 11 May 2021). [CrossRef] [PubMed] 
18. Rebosura, J.M.; Salehin, S.; Pikaar, I.; Kulandaivelu, J.; Jiang, G.; Keller, J.; Sharma, K.; Yuan, Z. Effects of in-sewer dosing of iron-rich drinking water sludge on wastewater collection and treatment systems. Water Res. 2020, 171, 115396. Available online: https: / / search.ebscohost.com/login.aspx?direct=true\&db=edselp\&AN=S0043135419311704\&site=eds-live\&scope=site (accessed on 11 May 2021). [CrossRef] [PubMed]

19. Klackenberg, L. Biomethane in Sweden-Market Overview Andpolicies, Swedish Gas Association 16 March 2021. 2021. Available online: https:/ / www.energigas.se/media/boujhdr1/biomethane-in-sweden-210316-slutlig.pdf (accessed on 14 May 2021).

20. Naturvårdsverket. Riktvärden för förorenad mark. Modellbeskrivning och vägledning. In Rapport 5976; Naturvårdsverket (Swedish Environmental Protection Agency): Stockholm, Sweden, 2009.

21. Berglund, M.; och Börjesson, P. Energianalys av Biogassystem. Rapport nr. 44; Institution för Teknik Och Samhälle, Avdelningen för Miljö- Och Energisystem; Lunds Tekniska Högskola: Lund, Sweden, 2003.

22. Nelsson, C. Varierande Gaskvalitet-Litteraturstudie. SGC-Rapport 209; Svenskt Gasteknisk Center: Malmö, Sweden, 2009. Available online: http:/ / www.sgc.se/ckfinder/userfiles/files/SGC209.pdf (accessed on 11 May 2021).

23. Persson, E. Årsrapport 2014 Certifierad återvinning, SPCR 120. Avfall Sveriges Utvecklingssatsning Rapport 2015:20. Available online: https:/ / www.avfallsverige.se/kunskapsbanken/rapporter/rapportera/article/arsrapport-2014-certifierad-atervinningspcr-120/ (accessed on 1 July 2021).

24. EU 2020: COM/2020/98 final. Communication from the Commission to the European Parliament, the Council, the European Economic and Social Committee and the Committee of the Regions: A New Circular Economy Action Plan for a Cleaner and More Competitive Europe. Available online: https:/ / eur-lex.europa.eu/legal-content/EN/TXT/?qid=1583933814386\&uri=COM:2020: 98:FIN (accessed on 11 May 2021). 